\title{
Pendampingan untuk Penyusunan Laporan Keuangan dan SPT Tahunan Yayasan Pendidikan Narayana Smriti Yogyakarta
}

\author{
Sang Ayu Putu Piastini Gunaasih ${ }^{1}$, Nuritomo ${ }^{2}$ \\ Universitas Atma Jaya Yogyakarta \\ sang.ayu@uajy.ac.id
}

\begin{abstract}
Abstrak - Pengabdian masyarakat ini ditujukan untuk memberikan pendampingan untuk penyusunan laporan keuangan dan SPT tahunan badan dengan format laporan ISAK 35. Pengabdian dilaksanakan di Yayasan Pendidikan Narayana Smriti Ashram yang berlokasi di kecamatan Maguwoharjo, Sleman. Yayasan tersebut baru saja terbentuk secara hukum pada awal tahun 2020 . Mitra mengalami kesulitan pada penyusunan laporan keuangan dan pelaporan SPT Tahunan karena minim pengalaman untuk pengurusan laporan dan penyusunan SPT Tahunan badan hukum non-laba. Segala kepentingan pendataan dari mitra dilakukan melalui survei dengan metode focus group discussion secara online. Penyusunan model laporan keuangan dibuat berdasarkan ISAK 35. Selanjutnya, pengisian SPT tahunan dilakukan secara elektronik melalui $e$-filling. Pelaksanaan diawali dengan pelatihan dan pendampingan dengan metode presentasi, diskusi tanya jawab, dan diakhiri penyusunan laporan keuangan dan SPT Tahunan. Hasil dari kegiatan ini menunjukkan yayasan memahami topik materi dan mampu menyelesaikan permasalahan perpajakan yang dihadapi.
\end{abstract}

Kata kunci - E-filling, ISAK 35, SPT Tahunan, yayasan.

\section{PENDAHULUAN}

\section{Latar Belakang}

Dinyatakan pada pasal 2 ayat 1 UU No. 36 tahun 2008 bahwa yang menjadi subyek pajak penghasilan adalah orang pribadi, warisan yang belum terbagi sebagai satu kesatuan, menggantikan yang berhak, badan, dan bentuk usaha tetap. Yayasan merupakan salah satu bentuk badan hukum yang kegiatannya tidak bersifat mencari laba (nonlaba). Menurut UU No. 28 tahun 2004, yayasan sebagai salah satu organisasi berbadan hukum nonlaba terdiri atas aset yang digunakan untuk kepentingan sosial berupa pendidikan, keagamaan, dan kemanusiaan. Perlakuan perpajakan yayasan memiliki kesamaan seperti pada organisasi profit atau komersial, baik dari sisi pelaporan ataupun sistem pemungutannya. Di dalam UU No. 28 tahun 2004, yang merupakan perubahan dari UU No. 16 tahun 2001, yayasan disejajarkan dengan organisasi berorientasi pada laba dan memiliki akta pendirian dan susunan kepengurusan sesuai hukum formal yang berlaku. Dari sisi pengenaan pajak, adanya selisih positif atas pendapatan dan biaya yang diperoleh oleh yayasan akan dikenakan pajak penghasilan. Sebelum melaporkan SPT, yayasan juga harus membuat laporan keuangan sesuai dengan kaidah yang telah ditentukan (Harjanti, dkk., 2019).

Yogyakarta sebagai salah satu kota pelajar memiliki cukup banyak badan hukum non-laba dalam bentuk yayasan. Salah satunya berlokasi di Kelurahan Maguwoharjo Kecamatan Kalasan bernama Yayasan Pendidikan Narayana Smriti. Yayasan ini resmi didirikan pada bulan Februari tahun 2020. Tahun 2021 menjadi tahun pertama yayasan tersebut melaporkan kewajiban perpajakannya. Yayasan Pendidikan Narayana Smriti adalah sebuah yayasan sosial keagamaan (kuil). Tujuan Pendidikan Narayana Smriti adalah menjalankan kegiatan sosial sebagai berikut:

1. Membentuk rumah pelayanan orang lanjut usia, mendirikan balai pengobatan, menyelenggarakan pendidikan informal seperti edukasi keterampilan, tempat belajar/taman pendidikan Veda (kitab suci agama Hindu), sanggar kebudayaan, dan keseniaan.

\section{Mendirikan tempat pelayanan jenazah}

3. Mengelola rumah ibadah/kuil, asrama menyalurkan sumbangan umat (dana punia) dan menyelenggarakan upacara keagamaan.

Pada saat awal terbentuk, Yayasan Pendidikan Narayana Smriti belum mempersiapkan laporan keuangan sesuai dengan kaidah pelaporannya. Laporan keuangan yang kurang sesuai akan menyulitkan saat pelaporan SPT tahunan yang akan dilaporkan pada akhir April tahun 2021. Tujuan dari penyusunan pencatatan keuangan selain untuk laporan pajak adalah agar pencatatan keuangan yang ada di Yayasan Pendidikan Narayana Smriti lebih tertata, mudah dipahami, dan berkualitas. Laporan keuangan yang dihasilkan juga akan memberikan informasi yang lebih akurat terutama terkait pencatatan donasi dari umat. Dengan informasi keuangan yang akurat, maka organisasi dapat menjalankan aktivitasnya dengan lebih efektif dan efisien. Hal ini juga dapat menjadi alat pertanggungjawaban bagi organisasi non-laba yang lebih baik. Selain itu peraturan perpajakan yang sering mengalami perubahan di setiap tahunnya mampu di update oleh pengurus agar menyajikan pelaporan sesuai dengan standar yang berlaku.

Secara garis besar, pelaporan perpajakan di Indonesia bersifat self-assessment system. Selfassessment system adalah sistem pemungutan pajak yang mana fiskus (aparatur pajak) memberikan 
Pendampingan untuk Penyusunan Laporan Keuangan dan

SPT Tahunan Yayasan Pendidikan Narayana Smriti Yogyakarta

wewenang dan kepercayaan kepada wajib pajak untuk mendaftar, menghitung, memperhitungkan, membayar, dan melaporkan kewajiban perpajakan. Oleh karena itu diperlukan pemahaman yang memadai untuk menghindari kesalahan ketika mengisi SPT tahunan bagi wajib pajak baik pribadi maupun badan. Selain itu, jika tidak melaporkan SPT Tahunan wajib pajak akan terancam sanksi perpajakan (Sari, 2020).

Ketentuan perpajakan di Indonesia menyatakan bahwa yayasan adalah subjek pajak badan yang memiliki hak dan kewajiban perpajakan sesuai undang-undang (UU) perpajakan yang berlaku. Oleh karena itu, untuk dapat menunaikan hak dan kewajiban perpajakannya, yayasan harus memiliki pengetahuan perpajakan yang memadai. Yayasan Pendidikan Narayana Smriti merupakan yayasan keagamaan yang baru berdiri dan mitra dalam hal ini pengurus yayasan belum memiliki pengetahuan dan pengalaman yang memadai terkait perpajakan dan laporan keuangan entitas non-laba.

Sesuai dengan ketentuan UU No.28 tahun 2004 pasal 48, Yayasan Pendidikan Narayana Smriti wajib menyusun laporan keuangan serta melaporkan SPT Tahunan Pajak penghasilan pada akhir periode dengan Standar Akuntansi Keuangan yang berlaku. Kartikahadi, dkk. (2012) menyatakan salah satu instrumen yang digunakan untuk pengambilan keputusan dalam suatu organisasi adalah berdasarkan laporan keuangannya. Laporan keuangan juga menjadi suatu indikator untuk mengukur performa dari suatu organisasi yang akan dipertanggungjawabkan kepada para penyedia dana. Laporan keuangan memberikan berbagai informasi penting terkait aset, ekuitas, utang, pendapatan, dan beban (Munte, 2017). Laporan keuangan pada organisasi laba dan non-laba memiliki perbedaan dalam penyusunan dan pelaporan keuangannya. Perbedaan mendasar pada kedua jenis organisasi tersebut terkait dengan tujuan yang ingin dicapai dari aset yang ada. Organisasi laba berorientasi pada pencarian keuntungan sebesar-besarnya yang digunakan untuk mengembangkan aset dari organisasinya. Sebaliknya, organisasi non-laba tujuan utamanya bukanlah profit-oriented melainkan untuk kepentingan sosial. Perbedaan mendasar tersebut menyebabkan kesulitan untuk melakukan pengukuran kinerja pada organisasi non-laba (Fatih, 2015). ISAK 35 adalah format pelaporan yang digunakan dalam penyusunan laporan keuangan untuk organisasi non-laba mengacu pada ISAK 35. ISAK 35 juga mencakup pada organisasi yang menerapkan format pelaporan SAK ETAP.

Berdasarkan ruang lingkup yang termuat dalam ISAK 35, Yayasan Pendidikan Narayana Smriti merupakan suatu entitas non-laba atau organisasi sektor publik yang seharusnya menggunakan ISAK 35 sebagai pedoman dalam menyusun laporan keuangannya. Namun, berdasarkan hasil wawancara kepada mitra (pengurus yayasan), Yayasan Pendidikan Narayana Smriti belum menggunakan ISAK 35 sebagai pedoman dalam membuat laporan keuangan entitasnya, bahkan mitra mengaku belum mengetahui tentang adanya ISAK 35 ini. Sehingga laporan keuangan yang telah disusun selama ini hanya menggunakan metode konvensional dan pengetahuan seadanya yang dimiliki oleh para pengurus.

\section{Identifikasi Masalah}

Dari hasil survei melalui focus group discussion bersama mitra, terdapat tiga poin permasalahan utama yang didapatkan, diantaranya:

1. Penggunaan metode pencatatan yang dilakukan belum sesuai standar yang berlaku. Pengurus yayasan masih menggunakan metode konvensional berdasarkan pencatatan kas masuk dan kas keluar. Hal ini berpotensi terjadi varian/selisih pada laporan keuangan.

2. Metode tradisional menyebabkan informasi sumbangan tidak jelas dengan jenis transaksi lainnya. Segala jenis transaksi menjadi satu dan tercampur. Keadaan ini berpotensi kurangnya informasi yang tepat mengenai posisi aset dan penggunaan dana donasi yang dimiliki yayasan

3. Belum mengetahui cara pelaporan SPT Tahunan secara online dengan menggunakan e-form.

\section{Manfaat}

Manfaat yang diharapkan dari proses pendampingan untuk penyusunan laporan keuangan dan pengisian SPT adalah pengurus mampu menerapkan format pelaporan keuangan berdasarkan ISAK 35 sehingga laporan keuangan yang disajikan menjadi lebih mudah dipahami, relevan, comparability (dapat dibandingkan) serta sesuai dengan standar yang berlaku di Indonesia. Informasi transaksi terkait donasi secara spesifik dijabarkan pada ISAK 35 (Isviandari dkk., 2021). Pada organisasi non-laba, donasi menjadi salah satu jenis transaksi utama dan cukup besar. ISAK 35 memberi penjelasan secara rinci terkait klasifikasi donasi dan kepentingan penggunaanya. Dengan mengacu pada ISAK 35 pengurus dapat menjadi lebih percaya diri untuk menyusun dan melaporkan kewajiban pajaknya sesuai waktu pelaporan.

Yayasan yang berbadan hukum wajib melaporkan SPT tahunan. Di era digital seperti sekarang ini pelaporan dapat dilakukan secara online melalui website Direktorat Jenderal Pajak (DJP). Heryanto dan Toly (2013) meneliti bahwa penyuluhan, dialog interaktif, dan iklan di media elektronik maupun cetak tidak berpengaruh terhadap penerimaan pajak. Pada penelitian ini menyebutkan bahwa, account representative (AR) 
di Kantor Pelayanan Pajak Pratama memiliki kontribusi yang sangat esensial dalam meningkatkan kepatuhan hukum bagi wajib pajak. Oleh karena itu, dengan cara diskusi kelompok antara AR dan wajib pajak akan meningkatkan kepatuhan menjalankan kewajiban perpajakan. Hal yang sama juga dilakukan Winerungan (2013) menyebutkan sosialisasi perpajakan, pelayanan fiskus, dan sanksi perpajakan tidak memiliki pengaruh terhadap kepatuhan wajib pajak orang pribadi. Berdasarkan hal tersebut di atas, pengabdian kepada masyarakat ini dilakukan dengan cara focused group discussion (FGD) dalam mempersiapkan laporan keuangan fiskal yang digunakan dalam pelaporan SPT Tahunan yang paling lambat dilaporkan pada 30 April 2021.

\section{Metode Pengabdian}

\section{Metode Pelaksanaan Kegiatan Pengabdian}

Beberapa tahapan pada pelaksanaan pengabdian diantaranya adalah:

1. Focus group discussion

Seperti yang terlihat pada gambar 1, beberapa kali pertemuan dengan metode focus group discussion (FGD) dilaksanakan secara online. Hal ini terkait dengan antisipasi penyebaran virus COVID-19 selama melakukan proses pendampingan. Informasi utama yang dapat diperoleh selama FGD diantaranya adalah jumlah transaksi dan jenis transaksi yang terjadi hingga sebelum tahap penyusunan laporan. Informasi lainnya terkait dengan hambatan dan kesulitan yang dialami selama ini terkait penyusunan dan pelaporan SPT Tahunan.

2. Modul laporan keuangan

Setelah mengetahui jenis dan jumlah transaksi yang terjadi selama ini, tahapan selanjutnya adalah mengklasifikasikan jenis-jenis transaksi tersebut sesuai dengan keperluannya. Proses klasifikasi mengacu pada format pelaporan keuangan ISAK 35. Setelah masing-masing jenis transaksi diidentifikasi dan diklasifikasikan, selanjutnya adalah pembuatan jurnal dan laporan keuangan.

3. Pendampingan penyusunan laporan keuangan dan pengisian SPT Tahunan

Pada tahap ini pengabdi melakukan pendampingan dan pelatihan penyusunan laporan keuangan kepada bendahara yayasan. Laporan keuangan yang telah disusun, dikoreksi fiskal sesuai ketentuan perpajakan. Laporan keuangan fiskal ini digunakan sebagai dasar penyusunan SPT Tahunan. Pelatihan ini bertujuan agar bendahara yayasan bisa menyusun laporan keuangan untuk entitas nonlaba, mengisi, dan melaporkan SPT tahunan secara lancar.

4. Pembuatan dokumentasi dan laporan akhir Tahap akhir pengabdian ini adalah tim pengabdi mengumpulkan dan mengolah seluruh kegiatan pengabdian masyarakat mulai dari pihak yayasan mengajukan permohonan pendampingan sampai dengan seluruh pelaporan SPT Tahunan secara online. Dokumentasi yang dihasilkan dari kegiatan ini antara lain modul singkat penerapan ISAK 35 dan pengisian SPT Tahunan melalui e-form. Sebagai bentuk pertanggungjawaban kepada pihak yayasan selaku pemohon dan pihak LPPM Universitas Atma Jaya Yogyakarta (UAJY) selaku pemberi dana maka dibuatlah dokumentasi dan laporan akhir ini.

\section{Lokasi dan Waktu Kegiatan}

Lokasi pengabdian dilaksanakan di Yayasan Pendidikan Narayana Smriti yang terletak di jalan Sudharsan Cakra No. 3, Depok, Denokan, Maguwoharjo, Kalasan, Sleman, Daerah Istimewa Yogyakarta 55281. Lokasi yayasan tersebut dapat dilihat pada map yang ditampilkan pada gambar 2 . Kegiatan dilakukan selama dua bulan, yaitu Maret dan April 2021.
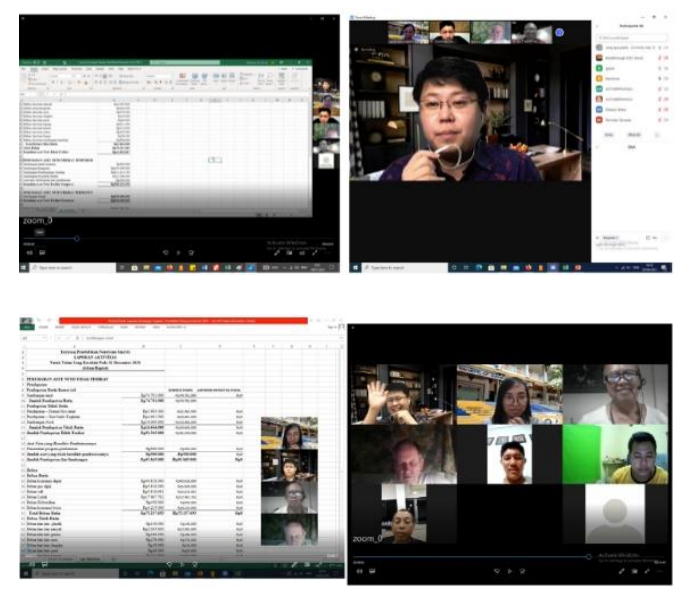

Gambar 1. FGD secara virtual tatap muka 


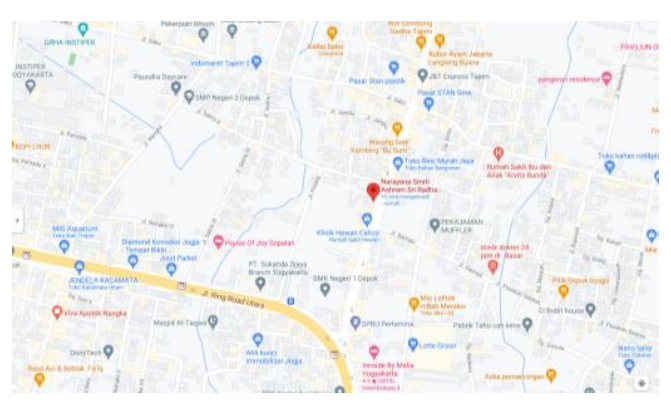

Gambar 2. Lokasi Yayasan Pendidikan Narayana Smriti melalui google map.

\section{HASIL DAN PEMBAHASAN}

Pengabdian diawali dengan adanya surat permohonan dari A. Govinda, selaku bendahara di Yayasan Pendidikan Narayana Smriti pada November 2020. Tahap pertama yang dilakukan adalah wawancara dan FGD. Untuk mengetahui secara jelas mengenai jenis pemasukan dan biaya, maka tim telah melakukan FGD dengan pihak pengurus. Berdasarkan hasil FGD diketahui beberapa hal berikut ini:

1. Sumbangan umat, dari uang yang wajib dibayar atas asrama yang ditempati oleh umat, sehingga termasuk sumbangan rutin dan merupakan penghasilan bukan obyek pajak sehingga dikoreksi fiskal negatif

2. Sumbangan donation box, dari kotak donasi (infak) yang ada di kuil. Sumbangan ini sifatnya tidak rutin dan merupakan penghasilan bukan obyek pajak sehingga dikoreksi fiskal negatif

3. Sumbangan tidak rutin lainnya, berasal dari sisa kegiatan keagamaan yang diadakan pada waktuwaktu tertentu. Sumbangan ini merupakan penghasilan bukan obyek pajak sehingga dikoreksi negative.

4. Pengeluaran konsumsi, terdiri dari belanja sembako

5. Pengeluaran utilitas, terdiri dari listrik dan wifi

6. Pengeluaran pemeliharaan, terdiri dari perawatan kuil seperti penggantian lampu

7. Pengeluaran kebersihan, terdiri dari iuran sampah

Laporan keuangan yang telah disusun berdasarkan dari proses wawancara disajikan pada tabel 1 . Laporan tersebut merupakan hasil rekapan segala jenis transaksi hingga bulan Desember 2020.
Tabel 1 Laporan Keuangan Yayasan Desember 2020

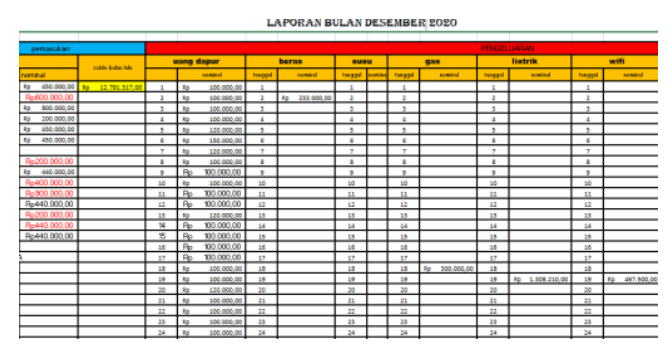

Kendala utama selama penyusunan laporan keuangan tersebut adalah laporan keuangan yang dicatat masih menggunakan selisih kas masuk dan keluar atau saldo kas berjalan. Metode ini menurut perhitungan akuntansi dinilai tidak relevan. Selain itu, dibutuhkan waktu dalam menyajikan kepada donatur. Laporan keuangan yang disajikan tidak sesuai dengan standar yayasan non-laba. Melalui pendampingan penyusunan laporan keuangan berdasarkan ISAK 35 diharapkan laporan keuangan yang disajikan lebih transparan dan akurat untuk dilaporkan ke donator/umat (Gunaasih, 2020). Untuk mengatasi masalah di atas, maka pengabdi membuatkan modul laporan keuangan berdasarkan ISAK 35 seperti yang ditampilkan pada gambar 3 .

Tahap kedua selama bulan Januari 2021 setelah FGD, pengabdi melakukan analisis transaksi yang terjadi di Yayasan, kemudian dilanjutkan pada bulan Februari 2021 pembuatan modul laporan keuangan berbasis ISAK 35. Selain itu pengabdi juga menyusun SPT Tahunan menggunakan $e$-form.



Gambar 3. Cover modul penyusuan laporan keuangan dan pengisian SPT.

Tahap ketiga, dilakukan pendampingan untuk penyusunan SPT tahunan. Pada pertemuan kali ini, dihadiri oleh seluruh pengurus yayasan dan 
Pendampingan untuk Penyusunan Laporan Keuangan dan SPT Tahunan Yayasan Pendidikan Narayana Smriti Yogyakarta

pembina yayasan. Ada berbagai pertanyaan yang diajukan oleh pengurus terkait dengan pepahaman dalam membuat laporan keuangan. Semua peserta aktif bertanya untuk memperoleh pemahaman yang sama. Seperti terlihat pada gambar 4, pendampingan penyusunan laporan keuangan dilakukan tiga kali pertemuan dan kemudian dilanjutkan dengan pengisian SPT Tahunan 1 pertemuan. Akhirnya pada 28 April 2021 SPT tahunan yayasan bisa di laporkan.

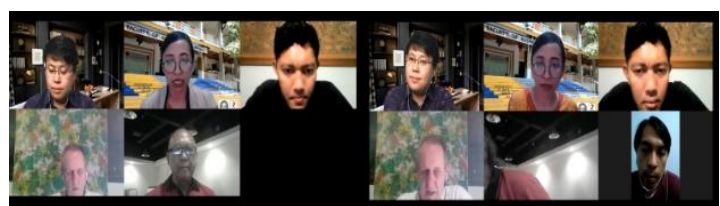

Gambar 4. Pendampingan pengisian SPT Tahunan

\section{KESIMPULAN}

Sesuai karakteristik organisasi non-laba, tim pengabdi telah sudah menerapkan ISAK 35 untuk membantu pengurus yayasan dalam penyusunan laporan keuangan dan pelaporan SPT tahunan. Melalui pendampingan ini, diharapkan yayasan mulai memahami pembuatan laporan keuangan sesuai dengan prinsip akuntansi dan juga pengisian SPT Tahunan melalui e-form. Sebagai bentuk pertanggungjawaban akan kesinambungan penyusunan laporan keuangan, tim pengabdi telah membuat modul yang bisa yayasan gunakan sebagai referensi dalam penyusunan laporan keuangan dan pelaporan SPT tahunan untuk tahun selanjutnya.

\section{UCAPAN TERIMAKASIH}

Kami mengucapkan terima kasih kepada LPPM Universitas Atma Jaya Yogyakarta atas dukungan dana yang telah diberikan selama proses pengabdian ini.

\section{DAFTAR PUSTAKA}

[1] Fatih, Mohammad. 2015. Implementasi Penyusunan Laporan Keuangan Pada Lembaga Nirlaba Yayasan Berdasarkan PSAK 45 (study Kasus pada Yayasan Pesantren Global Tarbiyyatul Arifin Kecamatan Pakis Kabupaten Malang). Ekononika Jurnal Ekonomi Universitas Kadiri 1(2)

[2] Gunaasih, SAPP. dan Harjanti, MGF. 2020. Pelatihan Penyusunan Laporan Keuangan Pura "Widya Dharma" Dero, Wedomartani, Ngemplak Sleman Berdasarkan PSAK 45. Prosiding SENDIMAS 2020 Vol.5 No.1

[3] Harjanti, RS., Mahmudah, N., Rahmadiane, GD., Alfarizi, Purwitasari. 2019. Praktik Pengisian Spt Wajib Pajak Badan Pada Siswa-Siswi Smk Karya Bhakti Kabupaten Brebes. Jurnal Abdimas PHB Vol. 2 No. 1

[4] Herryanto, M. dan Toly, AA. 2013. Pengaruh Kesadaran Wajib Pajak, Kegiatan Sosialisasi Perpajakan, dan Pemeriksaan Pajak terhadap Penerimaan Pajak Penghasilan di KPP Pratama Surabaya Sawahan. Tax \& Accounting

Review, 1(1), hal. 124.

[5] Isviandari, Diana, Mawardi. 2019. Pengaruh Penerapan PSAK 45 tentang Pelaporan Keuangan Entitas Nirlaba, Penerapan PSAK109, Pengendalian Internal, dan Kompetensi Sumber Daya Manusia terhadap Kualitas Laporan Keuangan Masjid-Masjid Di Kota Batu. Jurnal EJra Vol 08 (1)

[6] Kartikahadi, Hans. Sinaga, Rosita Uli. Syamsul, Merliyana. dan Siregar, Sylvia Veronica. 2012. Akuntansi Keuangan berdasarkan SAK berbasis IFRS. Jakarta Selatan. Salemba Empat.

[7] Munte, Franky Bigky dan Rahmah, Mulia. Perlakuan Akuntansi Organisasi Nirlaba Terkait dengan PSAK 45 Tahun 2017 Pada Gereja HKBP Maranatha. 2017. Jurnal Akuntansi dan Bisnis Universitas Krisnadwipayana

[8] Marsono dan Muamarah HS. 2019. Penghasilan Yayasan Keagamaan, Objek Pajak? Jurnal Kuat: Keuangan Umum dan Akuntansi terapan PKN STAN. Volume 1, Nomor 1, Maret 2019: Hal 49-56

[9] Sari, DP., Shanti, Handoko, J., Tedjasukmana, B., Hartanto, S. 2020. Pendampingan Pengisian SPT Tahunan Wajib Pajak Orang Pribadi Di Surabaya Tahun 2019. PeKA: Jurnal Pengabdian Kepada Masyarakat, Vol. 3 No. 1 Tahun 2020

[10] Winerungan, O. L. (2013). Sosialisasi Perpajakan, Pelayanan Fiskus dan Sanksi Perpajakan terhadap Kepatuhan WPOP di KPP Manado dan KPP Bitung. Jurnal EMBA: Jurnal Riset Ekonomi, Manajemen, Bisnis dan Akuntansi, 1(3)

[11] UU No. 36 Tahun 2008 Tentang Perubahan Keempat Atas Undang-Undang. Nomor 7 Tahun 1983 Tentang Pajak Penghasilan

[12] UU No. 28 Tahun 2004 Tentang Yayasan
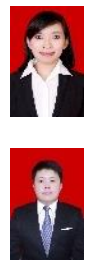

Sang Ayu Putu Piastini Gunaasih, prodi Akuntansi, Fakultas Bisnis dan Ekonomika, Universitas Atma Jaya Yogyakarta.

Nuritomo, prodi Akuntansi, Fakultas Bisnis dan Ekonomika, Universitas Atma Jaya Yogyakarta. 